\title{
LEVANTAMENTO DA FERTILIDADE DE SOLOS DA ESTAÇÃO EXPERIMENTAL DE PINDAMONHANGABA (*)
}

\author{
H. GaRgantini \\ Engenheiro-agrônomo, Seção de Fertilidade do Solo, Instituto Agronômico
}

\section{RESUMO}

Testes de fertilidade foram conduzidos com solos da Estação Experimental de Pindamonhangobo, pertencente oo Instituto Agronômico do Estodo de São Paulo.

Empregaram-se vasos de alumínio com capacidade de 1,5 quilos de terra cada um, pertencendo os solos a quatro séries: Pinda, Pinhão, Guatemala e Prateada. A planta empregada foi a alface romana e os materiais fertilizontes forom o nitrocálcio, - superfosfato e o sulfato de potássio. Fêz-se também calagem para correção da acidez dos solos, sendo do tipo dolomítico o calcário empregado.

Seis semenos após o tronsplante, colheu-se a porte aéreo das plontas, bem rente ao solo, que depois de sêcas foram pesodas. Pelos resultodos obtidos, as seguintes indicaçôes para experimentações podem ser tiradas.

Série Pinda: é indispensável o emprêgo de calagem, pois sua reação foi pronunciada. A seguinte fórmula básica deve ser empregada: $N_{1} P_{1} K_{2}$.

Série Pinhão: para esto série o uso de calagem é perfeitomente dispensável. Recomenda-se o seguinte fórmula básica: $N_{1} P_{3} K_{1}$.

Série Gustemala: a correção da acidez nesta série é pronunciada, pois seus efeitos foram notáveis, e a fórmula $N_{1} P_{3} K_{1}$ foi a que melhores resultados apresentou.

Série Prateada: além do emprêgo de colcário, que foi bastante significativo, recomenda-se a fórmula básica seguinte: $N_{1} P_{2} K_{1}$.

\section{1 - INTRODUÇÃO}

Para fins agrícolas, o levantamento pedológico de uma gleba qualquer deve ser completado com o estudo do fertilidade das unidades de solos encontradas.

(*) Trabalho apresentodo no VI Congresso Brasileiro de Ciência do Solo, realizodo em Salvador, Bahid, de 15 a 26 de julho de 1957.

Recebido para publicoçāo em 30 de dezembro de 1957. 
VoL. 17 , N. 13

Para o levantamento da fertilidade, ressaltam logo dois fatôres de grande importância. O primeiro é a determinação das séries e fases de solos, pelo estudo completo e detalhado da área, com a retirada de perfis, seu estudo morfológico, genético e finalmente o seu mapeamento. O segundo fator é a amostragem das unidades mapeadas, de modo a se obter uma amostra de fato representativa do nível de fertilidade da área em estudo.

Catani e outros (2) já demonstraram que o melhor sistema de se estudar a fertilidade de um solo é pela tomada de amostras compostas; que consiste na reunião de sub-amostras ou amostras simples, retiradas ao acaso, abrangendo tôda a área. Uma vez mapeado em série e determinados os níveis químicos, o estudo de sua fertilidade é necessário.

Já foi executado pelo Instituto Agronômico e Departamento de Águas e Energia Elétrica (5) o levantamento pedológico da Estação Experimental de Pindamonhangaba.

Êsse campo experimental se localiza no município de Pindamonhangaba, distando cêrca de $4 \mathrm{~km}$ dessa cidade, e localizando-se entre a mesma e a Via Presidente Dutra. Foi feito o estudo e o mapeamento dos solos que lá ocorrem, estabelecendo-se nove séries bem definidas.

$O$ objetivo do presente trabalho foi determinar os níveis de fertilidade em quatro das séries existentes no Estação, assim como as deficiências e necessidades daqueles solos em elementos nutritivos das plantas.

Tomamos amostras das séries Pinda, Pinhão, Guatemala e Prateada, tôdas de ocorrência generalizada no Vale do Paraíba. No capítulo 2 damos a descrição detalhada de cada uma destas séries.

\section{2 - SOLOS E GEOLOGIA}

Das séries empregadas neste estudo, três são originárias da formação Terciária e uma da Quaternária.

Conforme descrevem Küpper e outros (5), série é o grupo de solos provenientes de um mesmo material original, sujeito às mesmas condições de clima, vegetação, tempo e topografia. Baseados nestes autores, damos a descrição detalhada de cada série, assim como a descrição de um perfíl típico de cada uma delas, para perfeita caracterização das unidades estudadas. 


\section{1 - SERIE PINDA}

Classificação: - Grande grupo: latossolo amarelo-avermelhado. Grande tipo: terciário.

\section{Fatôres de formação}

Geologia: - Formazão geológica: Terciária.

Material original: sedimentos argilo-arenosos do terciório.

Topografia: - Relêvo: ondulado, 300 a $500 \mathrm{~m} / 20$ a $50 \mathrm{~m}$. Declividade: de 3 a $8 \%$.

Drenagem: boa.

Posição topográfica: partes altas.

Organismos: - Cobertura vegetal primitiva: mata.

Cobertura vegetal atual: dominante com pastos de capim gordura e do gênero Panicum.

Clima:

- Média anual de precipitação pluviométrica:

$1.213 \mathrm{~mm}$.

Mês de maior precipitação: dezembro, $194 \mathrm{~mm}$. Dias de chuva no ano: 128 dias.

Média anual de temperatura: $20,2^{\circ} \mathrm{C}$ (1954-56). Mês mais quente: janeiro, $33,8^{\circ} \mathrm{C}$ (máxima). Mês mais frio: agôsto, $9,4^{\circ} \mathrm{C}$ (mínima).

\section{Descrição de um perfil típico de mata:}

$\mathrm{A}_{11}$ - 0 a $6 \mathrm{~cm}$ : - $\mathrm{pH}$ de campo: 5,2; côr úmida: 10 YR 2/2 ('); textura: barro limoso; estrutura: granular média fracamente desenvolvida, rompe-se em granular fina a muito fino. Pouco pegajosa, pouco plástica, sôlta.

$\mathrm{A}_{12}$ - 6 a $12 \mathrm{~cm}$ : $-\mathrm{pH}$ de campo: 4,8; côr úmida: 10 YR 2/2 a $2 / 1$; textura: barro limoso; estrutura: sub-angular muito fina. Pouco pegajosa, pouco plástica, friável.

(') Côres dadas pela Tabela de Munsel. 
$\mathrm{A}_{31}$ - 12 a $25 \mathrm{~cm}$ : - pH de campo: 4,6; côr úmida: 10 YR 3/2; textura: argilosa; estrutura: sub-angular fina e muito fina, moderadamente desenvolvida, rompe-se em granular fina a muito fina. Pegajosa, plástica, friável.

$\mathrm{A}_{\text {::2 }}$ - 25 a $50 \mathrm{~cm}$ : - pH de campo: 4,6; côr úmida: 10 YR 3/3; textura: argilosa; estrutura: sub-angular média a fina, bem desenvolvida rompe-se em granular fina a média. Pegajosa, plástica, firme.

B.2 - 60 a $84 \mathrm{~cm}$ : - pH de campo: 4,6; côr úmida: 7,5 YR 3/4; textura: argilosa; estrutura: sub-angular média, moderadamente desenvolvida, rompe-se em sub-angular fina. Pegajosa, plástica, firme.

$\mathrm{B}_{3}-84$ a $104 \mathrm{~cm}:-\mathrm{pH}$ de campo: 4,6; côr úmida: $10 \mathrm{YR} 3 / 4$; textura: argilosa; estrutura: sub-angular média, fracamente desenvolvida, rompe-se em sub-angular muito fina a granular fina. Pegajosa, plóstica, friável.

$\mathrm{C}_{1}$ - 104 a $126 \mathrm{~cm}:-\mathrm{pH}$ de compo: 4,6; côr úmida: 7,5 YR 4/4; textura: argilosa; estrutura: sub-angular média, mal desenvolvida. Pegajosa, plástica, friável.

C. - 126 a $150 \mathrm{~cm}:-\mathrm{pH}$ de campo: 4,6; côr úmida: 5 YR 4/8 a 5/8; textura: argilosa; estrutura: sem, rompe-se em sub-angular média. Pegajosa, plástica, muito friável.

Data da coleta do perfil: 25-5-1956.

Altitude: $600 \mathrm{~m}$.

\section{2 - SÉRIE PINHÃO}

Classificação: - Grande grupo: latossolo amarelo-avermelhado. Grande tipo: Terciário.

\section{Fatôres de formação}

Geologia: - Formação Geológica: Terciário

Material original: sedimentos argilo-arenosos do Terciário. 
Topografia: - Relêvo: ondulado, 200 a $400 \mathrm{~m} / 20 \mathrm{~m}$.

Declividade: 5 a $8 \%$.

Drenagem: bem drenado.

Posição topográfica: meia encosta quando existe acima a série Pinda, do contrário, partes oltos.

Organismos: - Cobertura vegetal primitiva: mata.

Cobertura vegetal atual: dominante de pastos e algumas culturas como milho, cana-de-açúcar etc.

Clima: - Idêntico ao já detalhado para a Série Pinda.

\section{Descrição de um perfil típico}

$\mathrm{A}_{1 \mathrm{p}}$ e parte $\mathrm{A}_{3}-0$ a $20 \mathrm{~cm}$ : - $\mathrm{pH}$ de campo: 4,4, côr úmida: 10 YR 3/2; textura: barrenta a argilosa; estrutura: sub-angular grande, bem desenvolvida, rompe-se em sub-angular fina até grão simples. Poucoplástica, pouco pegajosa, firme.

$\mathrm{A}_{3}-20$ a $42 \mathrm{~cm}$ : - pH de campo: 4,0; côr úmida: 7,5 YR 4/2 a 4/4; textura: argilosa; estrutura: sub-angular, moderadamente desenvolvida, rompe-se em sub-angular fina, plástica, pegajosa, firme.

$\mathrm{B}_{1}$ - 42 a $60 \mathrm{~cm}$ : - pH de compo: 4,0; côr úmida: 7,5 YR 4/4 a 5/6; textura: argilosa; estrutura: sub-angular, moderadamente desenvolvida, rompe-seem sub-angular média a fina. Plástica, pegajosa, frióvel.

$\mathrm{B}_{2}-60$ a $90 \mathrm{~cm}$ : - $\mathrm{pH}$ de campo: 3,8; côr úmida: 5 YR 4/3 a 4/4; textura: argilosa; estrutura: sub-angular fina, moderadamente desenvolvida, rompe-se em sub-angular média a fina. Plástica, pegajosa, friável. 
$\mathrm{B} / \mathrm{C}$ - 90 a $107 \mathrm{~cm}$ : - pH de campo: 3,8; côr úmida: 5 YR 4/6 a 4/8; textura: argilosa; estrutura: subangular, moderadamente desenvolvida, rompe-se em sub-angular fina até grãos simples. Plástica, pegajosa, muito friável.

C - 107 a $150 \mathrm{~cm}:-\mathrm{pH}$ de campo: 3,8; côr úmida: 5 YR 5/8; textura: argilosa; estrutura: maciça, rompe-se em grãos simples. Pouco plástica, pouco pegajosa, muito friável.

Data da coleta do perfil: 22-8-1956.

Altitude: $580 \mathrm{~m}$.

\section{3 - SÉRIE GUATEMALA}

Classificação: — Grande grupo: Latossolo amarelo-avermelhado moderadamente drenado.

Grande tipo: Terciório.

\section{Fatôres de formação}

Geologia: - Formação geológica: Terciário.

Material original: sedimentos argilo-arenosos.

Topografia: - Relêvo: ondulado 300 a $500 \mathrm{~m} / 20$ a $50 \mathrm{~m}$. Declividade: 5 a $8 \%$.

Drenagem: moderadamente drenodo.

Posição topográfica: próximo a baixada.

Organismos: - Cobertura vegetal primitiva: mata.

Cobertura vegetal atual: dominantes de pastos com gramíneas e plantações de eucalíptos, mandioca etc.

Clima: _ - Idêntico ao já detalhado para a série Pinda.

\section{Descrição de um perfil típico}

$\mathrm{A}_{1}$, - 0 a $12 \mathrm{~cm}$ : - $\mathrm{pH}$ de compo: 4,6; côr úmida: 10 YR 3/4; textura: barrenta a argilosa; estrutura: granular médio, mal 
desenvolvida. Levemente pegajosa, pouco plásțica, muito friável.

$\mathrm{A}_{3}-12$ a $30 \mathrm{~cm}:-\mathrm{pH}$ de campo: 4,6; côr úmida: 10 YR 4/4 textura: argilosa; estrutura: maciça, com leve tendência para sub-angular. Pegajoso, pouco plástica, friável.

$\mathrm{B}_{1}$ - 30 a $46 \mathrm{~cm}:-\mathrm{pH}$ de campo: 4,4; côr úmida: 10 YR 4/4; textura: argilosa; estrutura: sub-angular em blocos, moderadamente desenvolvida. Pegajosa, friável.

$\mathrm{B}_{21}$ - 46 a $72 \mathrm{~cm}$ : - pH de campo: 4,4; côr úmida: 10 YR 4/4; textura: argilosa; estrutura: sub-angular em blocos, média, moderadamente desenvolvida. Pegajosa, pouco plástica, friável.

- 72 a $82 \mathrm{~cm}$ : - zona de transição.

$\mathrm{B}_{22}$ - 82 a $100 \mathrm{~cm}$ : - $\mathrm{pH}$ de campo: 4,4; côr úmida: 10 YR 4/4; textura: argilosa; estrutura: sob-angular em blocos, média, moderadamente desenvolvida. Pegajosa, pouco plástica, firme.

- 100 a $109 \mathrm{~cm}$ : - zona de transição.

$\mathrm{Cg}$ - 109 a $150 \mathrm{~cm}:-\mathrm{pH}$ de campo: 4,8; côr úmida: 2,5 YR 6/2 mosqueada côr 5 YR 4/8; textura: argilosa.

- Data da coleta do perfil: 17-4-1956.

- Altitude: $560 \mathrm{~m}$.

\section{4 - SERIE PRATEADA}

Classificação: - Grande grupo: Aluvião (azonal) Grande tipo: Baixada.

\section{Fatôres de formação}

Geologia: - Formação geológica: Quaternário.

Material original: sedimentos do Terciório e do Arqueano.

Topografia: - Relêvo: plano.

Declividade: 0 a $3 \%$.

Drenagem: má.

Posição topográfica: na várzea. 
Organismos: - Cobertura vegetal primitiva: mata. Cobertura vegetal atual: em cultura de arroz.

Clima: - Idêntico ao já detalhado para a série Pinda.

\section{Descrição de um perfil típico}

$A_{11}$ - 0 a $19 \mathrm{~cm}$ : — pH de campo: 4,2, côr úmida: 5 Y 5/3; textura: argilosa; estrutura: em adobe, rompe-se em sub-angular grossa. Muito plástica, pouco pegajosa, firme. Mosqueamento abundante e distinto, de côr 10 YR $4 / 3$ a $4 / 3$ e côr de ferrugem.

D - 19 a $28 \mathrm{~cm}$ : - pH de campo: 4,2; côr úmida: 10 YR 5/3 a $5 / 4$ em superfície livre, bastante mosqueado, de côr $10 \mathrm{YR}$ 5/8, 2,5 Y 4/0 e côr de ferrugem; textura: argilosa; estrutura: maciça. Muito plástica, pouco pegajosa, firme.

D - 28 a $49 \mathrm{~cm}$ : - pH de campo: 4,8; côr úmida $10 \mathrm{YR} 4 / 3$ na superfície lisa, bastante mosqueada de côr $10 \mathrm{YR} 3 / 1,10 \mathrm{YR}$ 5/6, 2,5 Y 4/2 e côr de ferrugem; textura: argilosa; estrutura: granular bem desenvolvida, rompe-se em sub-angular fina. Plástica, pouco pegajosa, firme.

D - 49 a $65 \mathrm{~cm}$ : - pH de campo: 4,8; côr úmida: 5 Y 4/1 com 7,5 YR 6/8; textura: barrenta; estrutura: granular média, bem desenvolvida. Muito plástica, pouco pegajosa, sôlta no lençol de areia, firme na argila e sôlta na areia.

D - 65 a $100 \mathrm{~cm}$ : $-\mathrm{pH}$ de campo: 5, l; côr úmida: 5 Y 4/1; textura: barrenta; estrutura: granular fina, bem desenvolvida. Muito plástica, pouco pegajosa, friável.

D - 100 a $150 \mathrm{~cm}$ : - $\mathrm{pH}$ de campo: 5,0; côr úmida: 5 Y 4/1, textura: argilosa; estrutura: granular, mal desenvolvida. Muito pegajosa, pouco plástica.

- Data da coleta do perfil: 25-4-1956.

- Altitude: $550 \mathrm{~m}$.

Observaçães: Todos os solos desta série estão em cultivo, razão pela qual o perfil se acha alterado pelo homem, ao formar os quadros de arroz. Há sinais de estratificações (lençóis de areia com argila), que for certo indicam antiga passagem de córregos. Em virtude do revol- 
vimento estabelecido no perfil, não se podem especificar perfeitamente os horizontes.

Solo com muita mica. A $60 \mathrm{~cm}$ existe um lençol de $5 \mathrm{~cm}$ de areia. $\mathrm{Na}$ profundidade de 28 a $49 \mathrm{~cm}$, existem muitas rázes, indicando que aí seria o horizonte $A$, antes de ser aterrado. As camadas de 0 $28 \mathrm{~cm}$ parecem ter sido colocadas para nivelar os quadros de arroz. A camada compreendida entre 65 a $100 \mathrm{~cm}$ é estratificada com lençóis argilosos e arenosos, com cêrca de $5 \mathrm{~cm}$ cada uma.

\section{3 - MATERIAL E MÉTODO}

Empregaram-se vasos de alumínio, com capacidade para 1,5 quilos de terra. Êles foram prèviamente pintados na parte interna com tinta preta fósca e exteriormente com esmalte branco e, a seguir, numerados. Os vasos assentavam sôbre coletores de alumínio, também esmaltados de branco.

As amostras dos solos testados foram retiradas de locais que nunca receberam adubaçōes. As amostras médias foram retiradas a uma profundidade entre zero (0) e quinze (15) cm, sêcas ao ar, muito bem homogeneizadas, e a seguir passadas através de uma peneira de $2 \mathrm{~mm}$ de abertura de malha.

As características físicas e químicas dêstes solos encontram-se no quadro 1.

O método por nós adotado no estudo da fertilidade dêstes solos foi o biológico (4), em que se emprega a alface romana como planta indicadora.

A alface romana é indicada para êstes testes por ser de rápido crescimento, resistente a pragas e moléstias, exigir um alto nível de elementos nutritivos no solo e, finalmente, poder-se selecionar as piantas na ocasião do transplante (3). Trabalhou-se com três níveis de nitrogênio, quatro de fósforo e três de potássio, além dos tratamentos com calcário.

Os tratamentos, de cada um havendo três repetições, foram: 1) $\mathrm{N}_{1} \mathrm{P}_{0} \mathrm{~K}_{0}$; 2) $\mathrm{N}_{1} \mathrm{P}_{1} \mathrm{~K}_{1}$; 3) $\mathrm{N}_{1} \mathrm{P}_{22} \mathrm{~K}_{1}$; 4) $\mathrm{N}_{1} \mathrm{P}_{3} \mathrm{~K}_{1}$; 5) $\mathrm{N}_{2} \mathrm{P}_{33} \mathrm{~K}_{1}$;

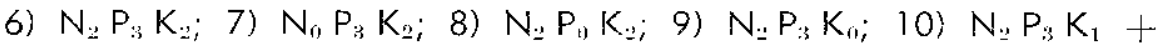
+ calcário; 11) $\mathrm{N}_{2} \mathrm{P}_{3} \mathrm{~K}_{2}+$ calcário.

Os fertilizantes empregados foram o nitrocálcio como fonte de $\mathrm{N}$, o superfosfato, como fonte de $\mathrm{P}_{., \mathrm{O}} \mathrm{O}_{\mathrm{i}}$ e o sulfato de potássio, como fonte de $\mathrm{K}_{2} \mathrm{O}$. 


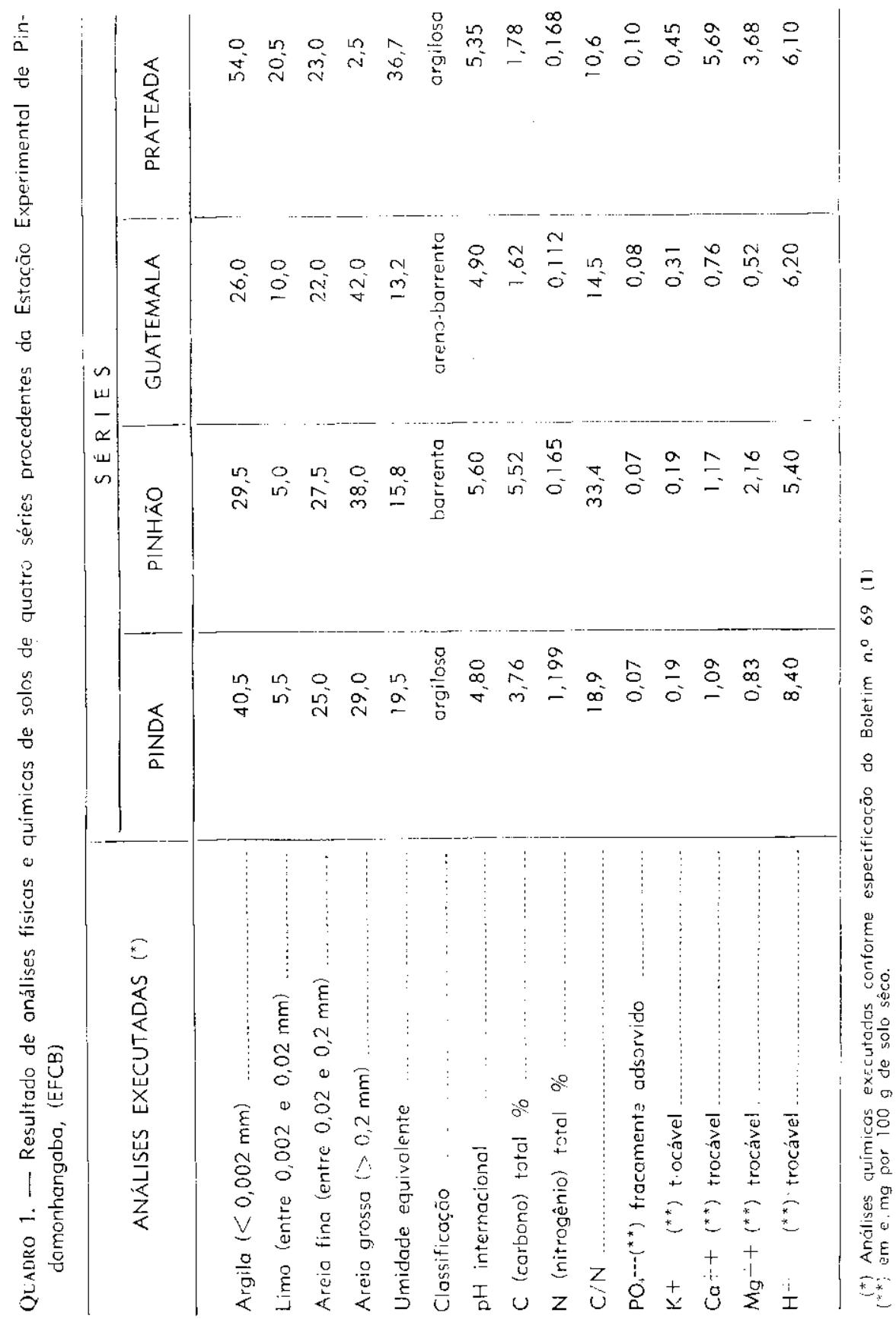


As doses usadas, assim como sua correspondência em quilos po? hectare foram:

\begin{tabular}{|c|c|c|c|c|c|c|}
\hline \multirow{2}{*}{ Dose } & \multicolumn{3}{|c|}{$\begin{array}{l}\text { mg por vaso } \\
(1,5 \mathrm{~kg} \text { de solo })\end{array}$} & \multicolumn{3}{|c|}{$\begin{array}{l}\mathrm{kg} \text { por hectare } \\
\text { (1 } 500000 \mathrm{~kg} \text { de solo) }\end{array}$} \\
\hline & $N$ & $P_{. .} \mathrm{O}_{\overline{.}}$ & $\mathrm{K}_{2} \mathrm{O}$ & $N$ & $\mathrm{P}_{2} \mathrm{O}_{7}$ & $\mathrm{~K}_{2} \mathrm{O}$ \\
\hline 1 & 50 & 100 & 50 & 50 & 100 & 50 \\
\hline 2 & 100 & 200 & 100 & 100 & 200 & 100 \\
\hline 3 & $\ldots$. & 400 & & $\cdots$ & 400 & $\cdots$ \\
\hline
\end{tabular}

Para o preparo dos vasos adotou-se a seguinte técnica: colocou-se aproximadamente $1 \mathrm{~kg}$ de terra e a seguir acrescentaram-se os materiais fertilizantes, misturando-os com o solo, para então juntar o restante de terra até perfazer a quantidade desejada. Nos vasos em que entrou como tratamento o calcário, o solo foi prèvia e intimamente misturado com o mesmo em bandeja à parte. A quantidade de calcário necessária a cada série foi determinada pelo teor de equivalentes- miligramas em hidrogênio trocável e pelo $\mathrm{pH}$. Baseados nestes dois resultados, calculou-se a quantidade necessária a cada série, como segue:

Série Pinda: $\quad 4,6 \mathrm{~g}$ por vaso ou 4600 quilos por hectare Série Pinhão: $\quad 2,6 \mathrm{~g}$ por vaso ou 2600 quilos por hectare Série Guatemala: $3,3 \mathrm{~g}$ por vaso ou 3300 quilos por hectare Série Prateada: 2,6 g por vaso ou 2600 quilos por hectare.

O calcário empregado foi do tipo dolomítico, com grau de finura dado pela peneira 50 , ou seja, com $0,3 \mathrm{~mm}$ de abertura de malha. Sua análise revelou: $27,6 \%$ de $\mathrm{CaO}$ e $19,2 \%$ de $\mathrm{MgO}$. O calcário foi misturado à terra dos vasos um mês antes do transplante das mudas de alface. Para melhor contato do calcário com o solo, foi êste mantido com umidade conveniente até a época do recebimento das mudas.

Como planta indicadora utilizamos a alface romana (Lactuca sit $t$ tiva L. var. longifolia) cujas sementes foram fornecidas pela Seção de Olericultura e Floricultura do Instituto Agronômico. As sementes ger- 
minaram em um substrato formado de terra e matéria orgânica na base de $50 \%$ cada. Trinta dias após, foram as mudinhas transplantadas uma para cada vaso.

Uma vez transplantadas as mudas de alface para os vasos, foram êles mantidos com umidade favorável e quando havia percolado era o mesmo retornado aos respectivos vasos. Foram feitas observações relativas oo desenvolvimento das plantas até a época da colheita.

Seis semanas após o transplante as plantas foram cortadas bem rente ao solo, picadas e colocadas em estufa para secagem a $60^{\circ} \mathrm{C}$ até pêso constante.

\section{4 - RESULTADOS E DISCUSSÃO}

Pelos resultados obtidos (quadro 2), podem-se verificar as produções de alface dos vasos, conforme os tratamentos, assim como seus valores relativos.

\section{1 - SÉRIE PINDA}

Os resultados analíticos dêste solo revelaram-no com acidez média para elevada, alto teor em carbono e em nitrogênio, bastante pobre em fósforo e com teor médio em potássio e em magnésio. $O$ teor em hidrogênio trocável é muito alto.

O tratamento 1 (testemunha) dá idéia da fertilidade desta série. Sua produção foi muito baixa, mostrando não ser bom o seu índice de fertilidade. Os tratamentos 7, 8 e 9 também tiveram produções muito baixas, mostrando a necessidade dêste solo nos três elementos fertilizantes essenciais. Ao que parece, pelo estudo das fórmulas completas pode-se notar não ter havido influência com o aumento de doses de nitrogênio, sendo a dose 1 a mais indicada. Para o fósforo, igualmente, não houve aumento de produção com a elevação das doses de $\mathrm{P}_{2} \mathrm{O}_{i,}$, podendo-se deduzir que a dose 1 já é suficiente para esta série. Com respeito ao potássio, foi notado aumento de produção da dose 1 para a 2, acarretando um acréscimo de produção em cêrca de $30 \%$. Para o calcário esta série apresentou grande reação, quando em presença de fórmulas completas, aumentos êstes de cêrca de 60 a $90 \%$ a mais do que a fórmula completa de $\mathrm{N}_{2} P_{3} \mathrm{~K}_{2}$. Para cálculo de valores relativos, foi dado 0 valor 100 à fórmula completa $N_{2} P_{3} K_{2}$, daí calculando-se os valores para os outros tratomentos. 


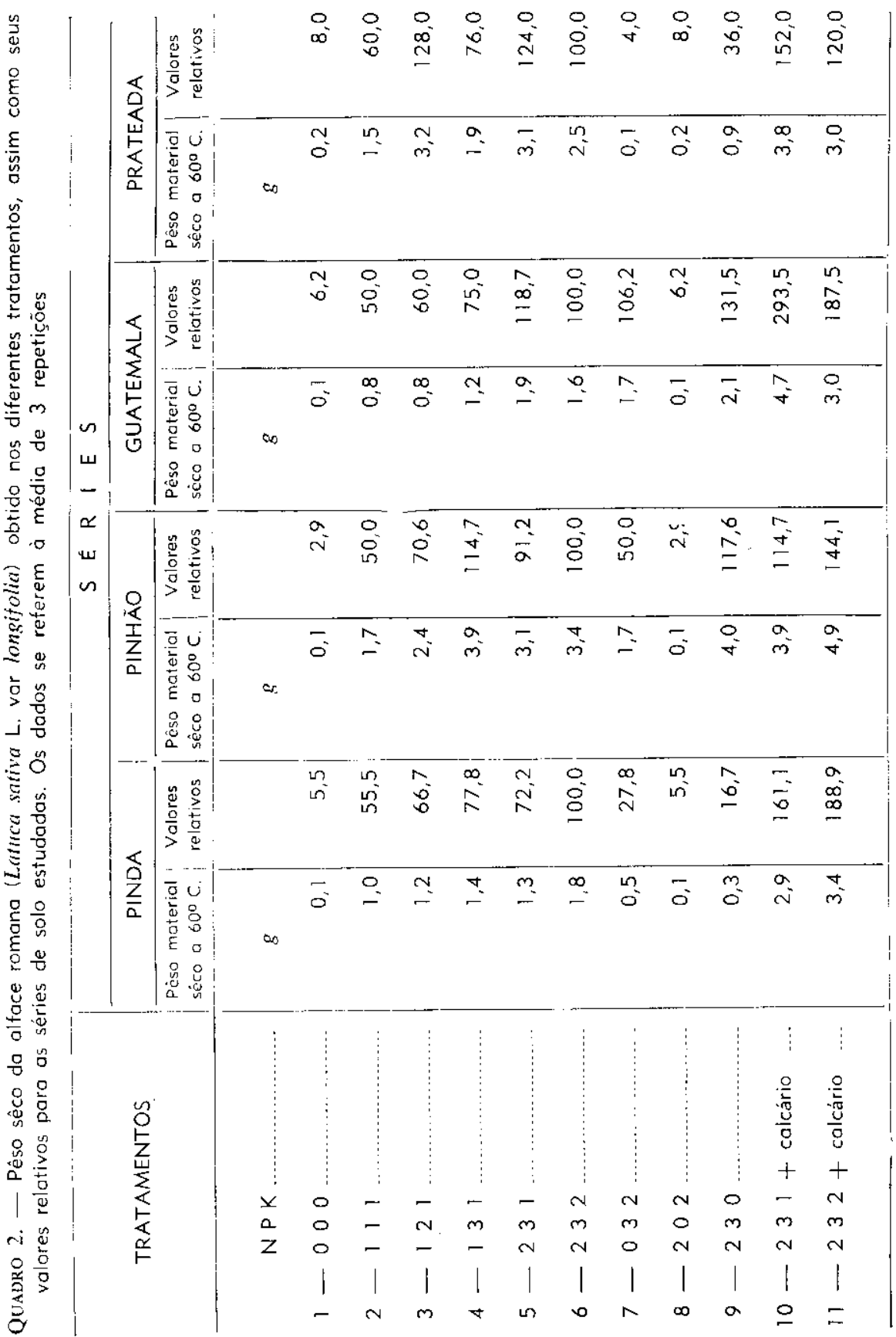


Para esta série recomendam-se ensaios de campo, empregando-se calagem e a fórmula 1-1-2, ou sejam 50-100-100 quilos de $N, P_{2} O_{\text {, }}$, e $\mathrm{K}_{2} \mathrm{O}$ por hectare, respectivamente.

\section{2 - SÉRIE PINHÃO}

A análise química dêste solo apresentou os seguintes resultados: acidez média para fraca, elevado teor em carbono e em nitrogênio, muito baixo teor em fósforo, médio em potássio e cálcio e alto em magnésio; o hidrogênio trocóvel apresentou um teor médio.

Pelos dados apresentados no quadro 2, nota-se perfeitamente não ter havido reação ao nitrogênio, parecendo indicar ser a dosagem 1 bastante suficiente. Para o potóssio parece que houve pequena reação com o aumento de doses. No tratomento em que não entrou êste elemento, a produção obtida foi muito boa. Porém, a dose 1 para o potássio parece ser a indicada. Para o fósforo a reação foi bastante nítida, sendo a melhor produção a obtida para a dosagem 3 dêste elemento. A reação ao calcário foi pouco nítida.

Paro esta série recomendam-se ensoios de campo com a fórmula 1-3-1, ou sejam, 50-400-50 quilos por hectare, de $\mathrm{N}, \mathrm{P}_{2} \mathrm{O}_{5}$ e $\mathrm{K}_{2} \mathrm{O}$, respectivomente.

\section{3 - SÉRIE GUATEMALA}

Os dados analíticos obtidos para esta série mostraram ser êste um solo de acidez média, alto teor em carbono, médio em nitrogênio, bastante pobre em fósforo, rico em potássio e magnésio e alto teor em hidrogênio.

Pelos resultados apresentados pelos testes com esta série, pode-se verificar o elevado efeito obtido com a aplicação de calcário, produzindo cêrca de 2 a 3 vêzes mais que o tratamento completo $N_{2} P_{3} K_{2}$. Vê-se, portanto, a elevada eficiência da aplicação de calagem nesta série. Ao nitrogênio sua reação não foi consistente, pois com o aumento da dose 1 para 2 mostrou aumento de produção,mas no tratamento em que êle estava ausente, a produção foi pràticamente igual ao tratamento completo. Para o potóssio, a reação apresentada foi pràticamente nula, não tendo havido aumento de produção com a aplicação dêste elemento. 
GaRgantinI

DEZ., 1958 
VoL., 17, N.o 13

Pora a série Guatemala, recomendam-se experiências com a fórmula 1-3-1 ou 50-400-50 quilos por hectare, de $\mathrm{N}, \mathrm{P}_{2} \mathrm{O}_{\overline{5}}$ e $\mathrm{K}_{2} \mathrm{O}$, respectivamente. $O$ emprêgo de calagem em solos desta série é imprescindível.

\section{4 - SÉRIE PRATEADA}

Esta série, por sua análise química, apresentou os seguintes teores: acidez média para fraca, carbono e nitrogênio com teores altos; bastante pobre em fósforo, riquíssima em potássio e magnésio e altos teores em cálcio e hidrogênio.

O quadro 2 e a figura 1, mostram os resultados obtidos com os testes nesta série.

Pelos resultados pode-se verificar que o nitrogênio apresentou reação, sendo indispensável a fertilização com êste elemento. $O$ fósforo também apresentou reação até a dose 2 , sendo que doses superiores a esto não apresentaram efeitos. A reação à aplicação de calagem foi bastante nítida, sendo indispensável a sua prática para esta série.

Recomendam-se para ela ensaios com a aplicação de calcário. A fórmula mais indicada é a 1-2-1 ou sejam 50-200-50 quilos por hectare de $\mathrm{N}, \mathrm{P}_{2} \mathrm{O}_{5}$ e $\mathrm{K}_{2} \mathrm{O}$, respectivamente.

\section{5 - CONCLUSÕES}

São as seguintes as conclusões que podem ser tiradas dos resultados obtidos com o presente ensaio.

a) Série Pinda: devem ser instaladas experiências com $0 \mathrm{em}-$ prêgo de calcário e com a fórmula básica $\mathrm{N}_{1} \mathrm{P}_{1} \mathrm{~K}_{2}$.

b) Série Pinhão: nesta série as experiências devem ser conduzidas com a fórmula $\mathrm{N}_{1} \mathrm{P}_{3} \mathrm{~K}_{1}$. $\mathrm{O}$ emprêgo de calagem é dispensável, pois a sua ação foi pouco nítida.

c) Série Guatemala: recomendam-se para esta série ensaios com a fórmula básica $N_{1} P_{3} K_{1}$. Deve-se fazer a correção do solo por meio de calagem, pois seu efeito nesta série foi bastante nítido.

d) Série Prateada: a fórmula básica para ensaios de campo com esta série deve ser a $N_{1} P_{2} K_{1}$, incluindo-se o emprêgo de calcário. 


\title{
SOIL FERTILITY SURVEY OF THE PINDAMONHANGABA AGRICULTURAL. EXPERIMENT STATION
}

\begin{abstract}
SUMMARY
The present paper deals with fertility tests carried out with soil samples from the Pindamonhangaba Agric. Exp. Sta., one of the branch stations of the Instituto Agronômico.

The samples were collected from four soil series: Pinda, Pinhão, Guatemalo, and Prateada. The test plants (romaine lettuce) were grown in oluminum pots containing $1.5 \mathrm{~kg}$ of soil. The following fertilizer were used: nitrocalcium, superphosphate, and sulfate of potash. The soil acidity was corrected with lime (dolomitic type).

Six weeks after planting the lettuce plants were harvested being cut at soil level, dried at $60^{\circ} \mathrm{C}$, and weighed. The results obtained suggest the following recommendations for future field experiments:

Pinda series: lime had a marked influence on the growth of the plants. The following basic formula is recommended: $N_{1} P_{1} K_{2.3}$.

Pinhão series: the use of lime did not fromote any response. The following basic formula is indicated: $N_{1} P_{3:} K_{1}$.

Guatemala series: there was a striking response to liming. The formula $N_{1} P_{3} K_{1}$ was the best.

Prateado series: in addition to the use of lime (results rather significant) the following basic formula is recommended: $N_{1} P_{2} K_{1}$.
\end{abstract}

\section{LITERATURA CITADA}

1. CATANI, R. A., GALLO, J. R. \& GARGANTINI, H. Amostragem de solo, métodos de análise, interpretação e indicaçōes gerais para fins de fertilidade. Campinas, Instituto agronômico, 1955.28 p. (Boletim n. ${ }^{\circ}$ 69)

2 \& CONAGIN, A. Amostragem de solo para estudo de fertilidade. Bragantic 14:[1]-26. 1954.

3. GALLO, A. A. Estudio de lo fertilidad de los suelos de la Estac. agric. exp. Palmira. Notas agron. 7:1-13. 1954.

4. JENNY, H., VLAMIS, 3. \& MARTIN, W. E. Greenhouse assay of fertility of California soils. Hilgardia 20:1-8. 1950.

5. KüPPER, A., VERDADE, F. C., HUNGRIA, L. S. le outrosl Levantamento pedológico da Estação Experimental de Pindamonhangaba. Trabalho apresentado no VI Congresso Brasileiro de Ciência do Solo, em Salvador — Bahia, 1957. [a publicar] 